\title{
Transcervical excision of a giant mediastinal parathyroid adenoma
}

\author{
Benjamin John Miller, ${ }_{1}^{1}$ Kim Isaacs, ${ }^{2}$ Emran Khan, ${ }^{3}$ Fausto F Palazzo ${ }^{4}$
}

'Department of Otolaryngology, St Mary's Hospital, London, UK ${ }^{2}$ Department of Endocrine Surgery, Imperial College Healthcare NHS Trust, London, UK

${ }^{3}$ Department of Medicine, Noble's Hospital, Isle of Man, UK ${ }^{4}$ Department of Endocrine Surgery, Hammersmith Hospital, London, UK

\section{Correspondence to} Benjamin John Miller, benjaminmiller@nhs.net

Accepted 6 January 2019

\section{DESCRIPTION}

A fit and active 53-year-old man was referred to his endocrinologist with incidentally identified hypercalcaemia $(2.8 \mathrm{mmol} / \mathrm{L})$ detected on routine blood tests. He reported a history of non-specific malaise and fatigue but no other symptoms. His history was only of surgery for a lumbar disc prolapse. Further laboratory tests revealed inappropriately raised parathyroid hormone (PTH) levels of $19 \mathrm{pmol} / \mathrm{L}$, normal vitamin $\mathrm{D}$ levels and raised urinary calcium in keeping with a diagnosis of primary hyperparathyroidism. Imaging demonstrated an asymptomatic $8 \mathrm{~mm}$ left renal calculus and normal bone density.

Parathyroid localisation studies revealed an unremarkable neck ultrasound, but technetium sestamibi imaging demonstrated an unusual linear region of increased intensity to the left of the mediastinum (figure 1) with similar washout to thyroid tissue suggesting possible ectopic thyroid tissue. A CT thorax with contrast was performed and demonstrated a well-defined, bilobed, uniformly enhancing mass to the left of the oesophagus, extending from the suprasternal notch and descending in the posterior mediastinum to the level of the carina, consistent with a giant mediastinal parathyroid adenoma (figure 2).

The patient underwent surgical excision of the lesion via a transcervical approach alone where a normal left superior parathyroid gland was seen and a giant posteroinferiorly prolapsed inferior parathyroid adenoma was found. The left recurrent laryngeal nerve was adherent to the anterolateral aspect of much of the adenoma and was carefully dissected off its surface to allow complete intact removal of the tumour. The intraoperative PTH measurements

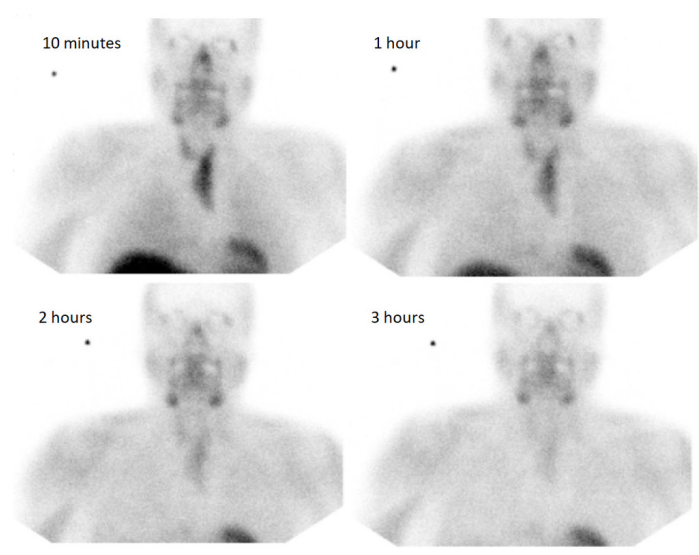

Figure 1 Technetium sestamibi imaging demonstrating an abnormal increased linear intensity to the left of the mediastinum.

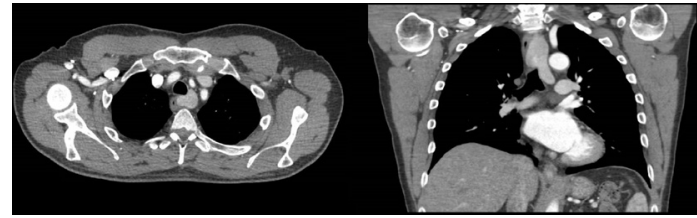

Figure 2 Axial and coronal CT thorax with contrast, demonstrating a well-defined, bilobed, uniformly enhancing mass in the posterior mediastinum to the left of the oesophagus, extending from the suprasternal notch to the level of the carina.

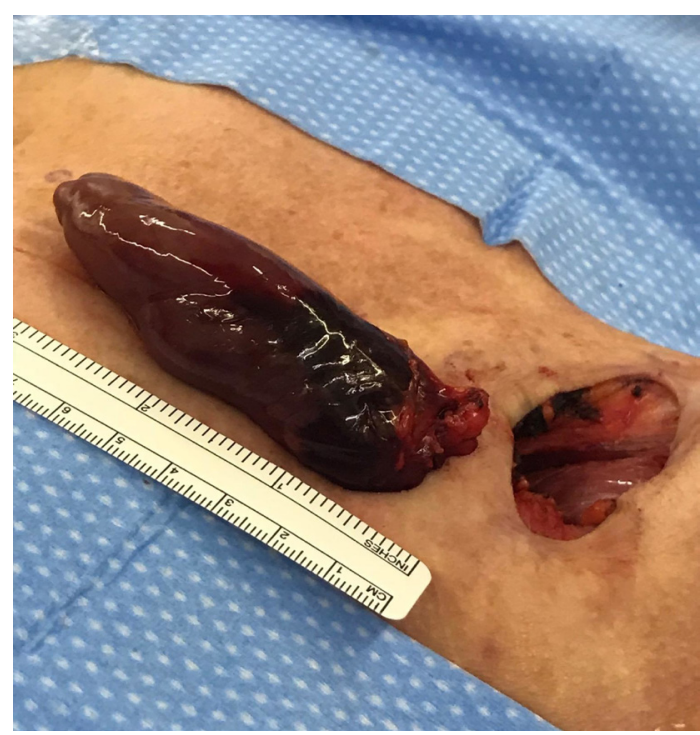

Figure 3 Macroscopic appearance of giant parathyroid adenoma excised at surgery.

fell from $36 \mathrm{pmol} / \mathrm{L}$ pre-excision to 9 and $7 \mathrm{pmol} / \mathrm{L}$ at 5 and 10 min postexcision, respectively. Postoperative calcium and PTH levels normalised, and he was discharged the day after surgery. Outpatient follow-up showed a full recovery, normal postoperative laryngoscopy and normal biochemistry. Histological review of the specimen revealed an $80 \times 30 \times 30 \mathrm{~mm}, 30.9 \mathrm{~g}$ parathyroid adenoma with no features of atypia or malignancy (figure 3 ).

Giant (>3.5 g) mediastinal parathyroid adenomas are extremely rare entities, with published instances limited to a handful of case reports. ${ }^{12}$ They are predominantly located in the anterosuperior mediastinum and may require a range of surgical approaches including transcervical, thoracoscopic, median sternotomy and thoracotomy. ${ }^{3}$ The latter three approaches are often preferred in deeper set adenomas, although sternotomy and thoracotomy 
have been shown to result in longer hospital stays and higher complication rates.

In our case, although deep set and posteroinferiorly prolapsed, the commencement of the adenoma in the anterosuperior mediastinum allowed for cautious stepwise retrieval via a transcervical approach. Inferior parathyroid glands normally descend into the anterior mediastinum. The case described is highly unusual in that owing to its size, much of this inferior adenoma prolapsed

\section{Learning points}

- Giant mediastinal parathyroid adenomas are a rare cause of primary hyperparathyroidism.

- Diagnosis rests on appropriate biochemistry and imaging including ultrasound, sestamibi but cross-sectional imaging of the neck and thorax may be required.

- A transcervical approach may be considered even in deepset mediastinal adenomas extending from the superior mediastinum with a low threshold for conversion to more invasive approaches if required. into the posterior mediastinum, a feature that can be encountered in large non-thymic inferior parathyroid adenomas. To our knowledge, the case described represents the largest non-cystic mediastinal parathyroid adenoma to be excised via a transcervical approach and underlines the importance of keeping an open mind when excising large mediastinal parathyroid adenomas.

Contributors All authors served as editors of the article. BJM wrote the initial draft with critical review and revisions from FFP, KI and EK.

Funding The authors have not declared a specific grant for this research from any funding agency in the public, commercial or not-for-profit sectors.

Competing interests None declared.

Patient consent for publication Not required.

Provenance and peer review Not commissioned; externally peer reviewed.

\section{REFERENCES}

1 Spanheimer PM, Stoltze AJ, Howe JR, et al. Do giant parathyroid adenomas represent a distinct clinical entity? Surgery 2013;154:714-9.

2 Dell'Amore A, Asadi N, Bartalena T, et al. Thoracoscopic resection of a giant mediastinal parathyroid cyst. Gen Thorac Cardiovasc Surg 2014:62:444-50.

3 Shields TW, Immerman SC. Mediastinal parathyroid cysts revisited. Ann Thorac Surg 1999:67:581-90.

Copyright 2019 BMJ Publishing Group. All rights reserved. For permission to reuse any of this content visit https://www.bmj.com/company/products-services/rights-and-licensing/permissions/

BMJ Case Report Fellows may re-use this article for personal use and teaching without any further permission.

Become a Fellow of BMJ Case Reports today and you can:

- Submit as many cases as you like

- Enjoy fast sympathetic peer review and rapid publication of accepted articles

- Access all the published articles

Re-use any of the published material for personal use and teaching without further permission

For information on Institutional Fellowships contact consortiasales@bmjgroup.com

Visit casereports.bmj.com for more articles like this and to become a Fellow 